\title{
Valuing the First Negotiated Repurchase of the TARP Warrants
}

\author{
Dr. Linus Wilson \\ Associate Professor of Finance, University of Louisiana at Lafayette \\ B. I. Moody III College of Business, 214 Hebrard Boulevard, Moody Hall 253 \\ P. O. Box 44570, Lafayette, LA 70504-4570
}

Tel: (337) 482-6209 E-mail: linuswilson@louisiana.edu

Website: http://www.linuswilson.com

Received: August 21, 2013 Accepted: Oct. 29, $2014 \quad$ Published: December 1, 2014

doi:10.5296/ajfa.v6i2.4160 URL: http://dx.doi.org/10.5296/ajfa.v6i2.4160

\begin{abstract}
On May 11, 2009, Old National Bancorp was the first publicly traded bank to buy back its Capital Purchase Program warrants. It paid \$1.2 million, which is below the low-end of this note's estimates of the fair market value of the warrants. This note estimates the warrants are worth between $\$ 1.5$ and $\$ 6.9$ million. This low negotiated price, from the perspective of taxpayers, indicates that the U.S. Treasury would probably get a better price marketing the CPP warrants to third party investors.
\end{abstract}

Keywords: Bailout, Banks, Banking, Capital Purchase Program, Emergency Economic Stabilization Act, Options, TARP, Valuation, Warrants

Journal of Economic Literature Codes: G01, G13, G21, G28, G32, G38 


\section{Introduction}

The Emergency Economic Stabilization Act of 2008 created the $\$ 700$ billion dollar Troubled Asset Relief Program (TARP). That legislation mandated the purchase of warrants in banks which sold assets to the U.S. Treasury. On October 13, 2009, U.S. Treasury Secretary Henry Paulson announced the Capital Purchase Program (CPP) to buy warrants and preferred stock in healthy banks. The CPP preferred stock pays dividends at 5 percent per annum for the first five years and 9 percent per annum thereafter. ${ }^{1}$ By March 31, 2009, over 500 financial institutions received funds totaling nearly $\$ 200$ billion dollars, according to SIGTARP (2009, p. 47). Closely held Centra Bank was the first bank to repurchase the TARP warrants. Nevertheless, because Centra was a privately held bank, its purchase agreement, which the bank management signed, specified that the cost of buying back the warrants would be five percent of the face value of the preferred stock investment. ${ }^{2}$ For publicly held banks, section 4.9 of the securities purchase agreement gives banks the right to repurchase the warrants at "fair market value."3

Old National Bancorp (ONB) was the first publicly held bank to negotiate its repurchase of the CPP warrants on May 11, 2009. Old National Bancorp, which is traded on the New York Stock Exchange under the ticker of ONB, received \$100 million dollars from the Capital Purchase Program on December 12, 2008. The company had $\$ 7.9$ billion in assets as of its last $10-\mathrm{K}$ filing. ONB was founded in Evansville, Indiana, in 1834. It is one of the top 100 bank holding companies in the United States in terms of assets. Nevertheless, it considers itself a community bank with operations in Indiana, Illinois, and Kentucky. With the approval of the Office of the Comptroller of the Currency and the Federal Reserve, ONB repurchased the preferred stock at par plus accrued dividends on March 31, 2009. On May 11, 2009, it became the first publicly traded bank to repurchase its CPP warrants, paying $\$ 1.2$ million for its 813,008 CPP warrants. ${ }^{4}$ Thus, it is the first example of the U.S. Treasury's ability to obtain the fair market value of the CPP warrants.

This is the first paper to value the ONB warrants just prior to the $\$ 1.2$ million deal struck with the U.S. Treasury. This paper finds that the management of ONB struck a good deal for its shareholders. Unfortunately for taxpayers, the deal struck is at below the author's range of estimates for the fair market value of the ONB warrants. This paper uses the methodology proposed in Wilson (2009) to value the CPP warrants of ONB. This paper finds that the ONB warrants are worth between $\$ 1.5$ million and $\$ 6.9$ million. These estimates are sensitive to assumptions as to whether or not ONB would have completed a Qualified Equity Offering

\footnotetext{
${ }^{1}$ Mark Landler and Eric Dash, October 15, 2008, "Drama Behind a \$250 Billion Banking Deal," New York Times, accessed online December 23, 2008 at http://www.nytimes.com/2008/10/15/business/economy/15bailout.html?.

2 Damian Paletta and Deborah Solomon, April 22, 2009, "Financial Firms Lobby to Cut Cost of TARP Exit," accessed online on April 27, 2009 at http://online.wsj.com/article/SB124035639380840961.html.

3 There is a flawed design in the appraisal process outlined in the securities purchase agreement's section 4.9. It has a split the difference resolution procedure that encourages the government, if it chooses to act in taxpayers' interest, to hire appraisers with optimistically high valuations of the warrants. On the other hand, it encourages banks to hire appraisal firms with extremely low valuations of the warrants. This flawed resolution procedure makes the appraisal process less informative than a well designed mechanism could have produced.

${ }^{4}$ Press Release, May 11, 2009, "Old National Bancorp Repurchases Warrant From U.S. Treasury," accessed online on May 11, 2009 at http://www.snl.com/irweblinkx/file.aspx?IID=100391\&FID=7780588
} 
(QEO) on or before December 31, 2009. ${ }^{5}$ They also depend on estimates of the dividend yield and the volatility of ONB's stock price over the next 9.6 years.

\section{Data and Inputs}

The valuation was conducted based on the closing share price and the last option trade on May 8, 2009. Friday, May 8, 2009, was the last trading day before the agreement was announced by ONB on Monday, May 11, 2009, in an 8-K filing, and a press release on its website. With the exception of the option price data on May 8, 2009, which was taken from www.prophet.net, all data was obtained from Yahoo! Finance.

Dividend yield was estimated by finding the average dividend yield from January 1, 2002, to May 8, 2009. The dividend paid was divided by the ex dividend day's closing stock price. This dividend yield was compounded so that the yield was annualized. Then the annualized yield was converted into a continuously compounding yield so that it would be compatible with the continuous time models of Merton (1973) and Black and Scholes (1973). Over this period the continuously compounding yield was 3.93 percent. This was used as the middle estimate for dividend yield. The high estimate of dividend yield was 1.5 times the average continuously compounded dividend yield, or 5.89 percent. The lowest estimate of dividend yield was the dividend yield based on the announced forward dividend of $\$ 0.07$ per share divided by the closing share price of $\$ 14.70$ on May 8,2009 . ONB recently cut its dividend from $\$ 0.23$ per share to $\$ 0.07$ cents pre share. Since dividends reduce the value of call options and warrants, the low-end valuation used the highest dividend yield, and the high-end valuation used the lowest dividend yield.

The middle estimate of volatility is based on the Black and Scholes (1973) implied volatility of the closing price of the $\$ 17.50$ call option that expires on June 19, 2009. Two hundred and fifty contracts were traded on May 8,2009 . The closing call option price was $\$ 0.35$, and the closing stock price was $\$ 14.70$. The implied volatility was estimated at 59.72 percent. The three month T-bill rate of 0.15 percent was used as the risk-free rate in the implied volatility calculation.

The low and high estimates of volatility were obtained by using the procedure of Hull (2003, pp. 238-241) after adjusting the stock price for several stock dividends. Stock dividends increase the number of shares outstanding. Thus, the stock price should fall on the day of the stock dividend. The adjustment, in theory, should have reduced the historic volatility of the stock and more accurately reflects the volatility of the stock's returns.

The low-end estimate of volatility was 37.10 percent. It was derived from daily closing stock prices and quarterly dividends paid from January 1, 2002, to May 8, 2009. The standard deviation of the lower estimate is 0.61 percent. The high-end estimate was 72.89 percent. It

\footnotetext{
5 A qualified equity offering according to the CPP term sheet page 2 “'Qualified Equity Offering' shall mean the sale by the QFI [Qualified Financial Institution] after the date of this investment of Tier 1 qualifying perpetual preferred stock or common stock for cash." Source: U.S. Treasury, "TARP Capital Purchase Program Senior Preferred Stock and Warrant Summary of Senior Preferred Terms" at http://www.financialstability.gov/docs/CPP/termsheet.pdf
} 
was based on daily closing stock prices and quarterly dividends from January 1, 2008, to May 8,2009 . The standard deviation of this volatility estimate is 2.80 percent. 2008 and 2009 have been unusually volatile years for the stock market. ${ }^{6}$ Since warrants are more valuable when the volatility is higher, the low-end valuation uses the lowest volatility number, and the high-end valuation uses the highest valuation estimate. Thus, 37.10, 59.72, and 72.89 percent were used as the volatility estimates in the low, middle, and high warrant valuations, respectively.

The CPP warrants have an unusual provision that cancels half of the warrants if the institution issues preferred or common stock in the amount of the CPP investment prior to January 1, 2010, but no earlier than the date that the CPP funds were disbursed to the bank. Thus, the expected number of warrants has been reduced by the probability that ONB would have sold preferred or common stock in the amount of $\$ 100$ million by December 31, 2009. The author subjectively put a fifty percent probability of such an issuance in the low-end valuation, a thirty percent probability of such an issue in the middle valuation, and a ten percent chance of such an issue in the high-end valuation. This translated into the expected number of warrants outstanding by the end of 2009 at $609,756,691,057$, and 772,358 in the low, middle, and high valuation scenarios. Despite the fact the U.S. Treasury owned 813,008 warrants, the expected number of warrants is less than that because of the warrant reduction provisions in the CPP term sheet. After looking through ONB's recent press releases and 8-K filings, the author was not able to find any evidence that ONB had initiated any preferred or common stock offerings since receiving the CPP funds. Therefore, it seems unlikely that it would have completed a qualified equity offering prior to the start of 2010 . The author nevertheless cautions the reader that his estimates about warrant cancellation probabilities are highly subjective.

Table 1 provides many of the inputs used in the valuation in Tables 2,3 , and 4 . These are the number of shares outstanding, the number of warrants, the closing stock prices and the strike price of the warrants. All the valuations used a continuously compounding, risk-free rate of 3.19, percent which was based on the ten year Treasury note rate reported for May 8, 2009, on Yahoo! Finance.

\section{Models and Results}

The most preferred model adjusts for dividends and the dilution associated with warrant exercise. When warrants are exercised, the number of shares increase. On May 8, 2009, the number of shares outstanding was 66.41 million. Thus, if all warrants were exercised, then the number of shares would increase by 0.81 million. Galai and Schneller (1978) adjust for the capital raised from warrant exercise, because the exercise price is collected by the firm. That model also adjusts for the dilution associated with the extra stock circulating. On balance, warrant exercise puts downward pressure on the stock price. Galai and Schneller (1978)'s methods were used to adjust the estimates generated from the option pricing model of Merton (1973). Merton (1973) shows how to estimate option prices for stocks which pay

\footnotetext{
${ }^{6}$ Brad Hessel, April 24, 2009, "The Volatility is off the Charts!” The Motley Fool, accessed online on April 29, 2009 at http://www.fool.com/investing/general/2009/04/24/this-volatility-is-off-the-charts.aspx.
} 
continuous dividends. Merton (1973) is a good estimate for a long lived call option such as warrant with almost ten years to expiration. The warrant values were solved numerically and are summarized in Table 2. The per-warrant valuation is the lowest in Table 2 because the dilution and dividend adjustments reduce the warrants' value. The per-warrant values are $\$ 2.50, \$ 5.93$, and $\$ 8.88$ in Table 2 in the low, middle, and high scenarios, respectively.

In Table 3, only the model of Merton (1973) is used. The warrants are adjusted downwards for dividends, but no adjustments are made for dilution. The per-warrant values in Table 3 are $\$ 2.52, \$ 3.63, \$ 8.91$. If we compare the results in Table 2 and Table 3, dilution only cost a few cents per-warrant.

In Table 4, the Black and Scholes (1973) model is used. It does not adjust for either dilution or dividends. Thus, Table 4 generates the highest values per-warrant. The per-warrant values are \$6.72, \$9.69, and \$11.05 in the low-end, medium, and high-end valuations. This is significantly higher than the other two tables. Black and Scholes (1973) significantly overstates the values of the CPP warrants because that model does not adjust for dividends. Since financial stocks are heavy dividend payers, any realistic valuation of their warrants must adjust for dividends.

\section{Conclusion}

This paper has valued the Old National Bancorp (ONB) warrants which were issued as part of this bank's brief participation in the Capital Purchase Program (CPP). In the author's most preferred model, the middle estimate was that the CPP ONB warrants were worth $\$ 3.61$ million. This is significantly higher than the $\$ 1.2$ million price that the U.S. Treasury sold them back to ONB. The low-end and high-end estimates of the warrants value in the preferred model of Galai and Schneller (1978) and Merton (1973), which provides the lowest estimates of the warrants' value, in Table 2 are $\$ 1.5$ million and $\$ 6.9$ million, respectively. Therefore, the first negotiated repurchase of the CPP warrants should worry taxpayers. The U.S. Treasury negotiated a price below what could be considered fair market value.

U.S. taxpayers do not appear to be receiving fair market value for the risky securities that they purchased. Policy makers should be troubled because Wilson (2009) estimates that the CPP warrants could be worth between $\$ 5$ billion and \$24 billion based on May 1, 2009, closing prices. It could mean billions of dollars in lost revenue if the U.S. Treasury continually negotiates deals at the low-end of or below fair market value. Further, if the U.S. Treasury agrees to sell the CPP warrants below fair market value, then the estimates of the subsidies involved in the CPP investments by the Congressional Budget Office (2009) and the Congressional Oversight Panel (2009) may be significantly underestimated. In other words, the estimated paper losses in Congressional Budget Office (2009) and the Congressional Oversight Panel (2009) reports may turn out to be much larger when they are locked in by poor negotiations by the U.S. Treasury.

Many readers will not be surprised by this result. U.S. Treasury officials' incentives are not as well aligned with the interests of taxpayers as bank managers' incentives are aligned with the interests of their shareholders. For this reason, we should probably continue to expect the 
U.S. Treasury to negotiate a price that is below or on the low-end of the fair market value of the CPP warrants. Without a major change in the structure of compensation in the federal bureaucracy, which seems nearly impossible, the best hope for taxpayers is to sell the warrants to third party investors. Third party investors competing against each other will get the best price for the U.S. taxpayer. The U.S. Treasury is comfortable marketing the U.S. national debt to investors all over the world. Whenever possible, it should seriously consider doing the same with the CPP warrants even if this means hiring an independent brokerage firm, asset manager, or investment bank to market these securities.

\section{References}

Black, F., \& Scholes, M. (1973). The pricing of options and corporate liabilities. Journal of Political Economy, 81, 637-654. http://dx.doi.org/10.1086/260062

Congressional Budget Office. (2009). The Troubled Asset Relief Program: report on transactions through December 31, 2008. Accessed online on May 6, 2009 at http://www.subsidyscope.com/projects/bailout/documents/15/.

Congressional Oversight Panel. (2009). February 6, 2009, February Oversight Report: Valuing Treasury's Acquisitions. Accessed online on May 5, 2009, at http://cop.senate.gov/reports/library/report-020609-cop.cfm.

Galai, D., \& Schneller, M. I. (1978). Pricing of warrants and the valuation of the firm. Journal of Finance, 33, 1333-1342. http://dx.doi.org/10.1111/j.1540-6261.1978.tb03423.x

Hull, J. (2003). Options, Futures and Other Derivatives. $5^{\text {th }}$ ed. Pearson Hall: Upper Saddle River, New Jersey.

SIGTARP. (2009). Office of the Special Inspector General for the Troubled Asset Relief Program, Quarterly Report to Congress: April 21, 2009. Accessed online on May 5, 2009, at http://www.sigtarp.gov/reports/congress/2009/April2009_Quarterly_Report_to_Congress.pd.

Wilson, L. (2009). The Goldman Sachs warrants. Review of Business, 30, 4-32. 
Table 1. Summary Statistics for Old National Bank Corp on May 8, 2009

\begin{tabular}{|l|l|l|l|}
\hline $\begin{array}{l}\text { Shares Oustanding } \\
\text { (Millions) }\end{array}$ & 66.41 & CPP Strike Price & $\$ 18.45$ \\
\hline $\begin{array}{l}\text { New Shares After } \\
\text { Exercise (Millions) }\end{array}$ & 0.81 & Closing Share Price & $\$ 14.70$ \\
\hline $\begin{array}{l}\text { Total Shares with 100 Percent Warrant Exercise } \\
\text { (Millions) }\end{array}$ & 67.22 & Maket Cap (Millions) & $\$ 976.23$ \\
\hline
\end{tabular}

Shares outstanding, the closing share price, and market capitalization data was obtained from Yahoo! Finance after the close of trading on May 8, 2009. The CPP new shares after exercise and CPP strike price are taken from SIGTARP (2009, p. 219).

Table 2. Valuation of Old National Warrants on May 8, 2009, Adjusting for Dividends with Merton (1973) and Dilution with Galai and Schneller (1978)

\begin{tabular}{|l|l|l|l|}
\hline & Low & Middle & High \\
\hline Volatility & $37.10 \%$ & $59.72 \%$ & $72.89 \%$ \\
\hline Dividend Yield & $5.89 \%$ & $3.93 \%$ & $1.90 \%$ \\
\hline Probability That Half Warrants Will Be Cancelled & $50 \%$ & $30 \%$ & $10 \%$ \\
\hline Expected Number of Warrants & 609,756 & 691,057 & 772,358 \\
\hline Per Warrant Value (\$) & $\mathbf{\$ 2 . 5 0}$ & $\mathbf{\$ 5 . 9 3}$ & $\mathbf{\$ 8 . 8 8}$ \\
\hline Total Value of Warrants (\$ Millions) & $\mathbf{\$ 1 . 5 2}$ & $\mathbf{\$ 4 . 0 9}$ & $\mathbf{\$ 6 . 8 6}$ \\
\hline
\end{tabular}

The low-end volatility is the annualized historic volatility. This is obtained from calculating the daily instantaneous returns from January 1, 2009, to May 8, 2009, using the procedure outlined in Hull (2003, pp. 238-241) and Wilson (2009). The high-end volatility is also based on historic volatility of the stock from January 1,2008 , to May 8,2009 . The middle volatility estimate is based on the implied volatility of the $\$ 17.50$ June 2009 call options traded on May 8, 2009. The middle estimate of dividend yield is based on the average dividend yield from January 1, 2002, to May 8, 2009, adjusted for continuous compounding. The low-end estimate's dividend yield is 1.5 times the middle estimate. The high-end valuation's dividend yield it the forward dividend yield based on the announced dividend of $\$ .07$ per share and the May 8, 2009, closing stock price of $\$ 14.70$ adjusted to be an annualized continuously compounding rate. The historic option price data was obtained on www.prophet.net. The stock price data was taken from Yahoo! Finance. The probability that half the warrants will be cancelled is the subjective probability given by the author of the likelihood of a qualified equity offering being completed by December 31, 2009. Completion of a qualified equity offering would allow the bank to cancel half the warrants. The per-warrant value is calculated with the inputs in this table and the stock price and strike price in Table 1 using the Merton (1973) model with the dilution adjustments proposed by Galai and Schneller (1978). 
Table 3. Valuation of Old National Warrants on May 8, 2009, Adjusting for Dividends with Merton (1973)

\begin{tabular}{|l|l|l|l|}
\hline & Low & Middle & High \\
\hline Volatility & $37.10 \%$ & $59.72 \%$ & $72.89 \%$ \\
\hline Dividend Yield & $5.89 \%$ & $3.93 \%$ & $1.90 \%$ \\
\hline Probability That Half Warrants Will Be Cancelled & $50 \%$ & $30 \%$ & $10 \%$ \\
\hline Expected Number of Warrants & 609,756 & 691,057 & 772,358 \\
\hline Per Warrant Value (\$) & $\mathbf{\$ 2 . 5 2}$ & $\mathbf{\$ 5 . 9 6}$ & $\mathbf{\$ 8 . 9 1}$ \\
\hline Total Value of Warrants (\$ Millions) & $\mathbf{\$ 1 . 5 4}$ & $\mathbf{\$ 4 . 1 2}$ & $\mathbf{\$ 6 . 8 8}$ \\
\hline
\end{tabular}

The low-end volatility is the annualized historic volatility. This is obtained from calculating the daily instantaneous returns from January 1, 2009, to May 8, 2009, using the procedure outlined in Hull (2003, pp. 238-241) and Wilson (2009). The high-end volatility is also based on historic volatility of the stock from January 1,2008 , to May 8,2009 . The middle volatility estimate is based on the implied volatility of the $\$ 17.50$ June 2009 call options traded on May 8, 2009. The middle estimate of dividend yield is based on the average dividend yield from January 1, 2002, to May 8, 2009, adjusted for continuous compounding. The low-end estimate's dividend yield is 1.5 times the middle estimate. The high-end valuation's dividend yield it the forward dividend yield based on the announced dividend of $\$ .07$ per share and the May 8, 2009, closing stock price of $\$ 14.70$ adjusted to be an annualized continuously compounding rate. This option price data was obtained on www.prophet.net. The stock price data was taken from Yahoo! Finance. The probability that half the warrants will be cancelled is the subjective probability given by the author of the likelihood of a qualified equity offering being completed by December 31, 2009. Completion of a qualified equity offering would allow the bank to cancel half the warrants. The per-warrant value is calculated with the inputs in this table and the stock price and strike price in Table 1 using the Merton (1973) model with no dilution adjustments.

Table 4. Valuation of Old National Warrants on May 8, 2009, Using Black Scholes (1973)

\begin{tabular}{|l|l|l|l|}
\hline & Low & Middle & High \\
\hline Volatility & $37.10 \%$ & $59.72 \%$ & $72.89 \%$ \\
\hline Probability That Half Warrants Will Be Cancelled & $50 \%$ & $30 \%$ & $10 \%$ \\
\hline Expected Number of Warrants & 609,756 & 691,057 & 772,358 \\
\hline Per Warrant Value (\$) & $\mathbf{\$ 6 . 7 2}$ & $\mathbf{\$ 9 . 6 9}$ & $\mathbf{\$ 1 1 . 0 5}$ \\
\hline Total Value of Warrants (\$ Millions) & $\mathbf{\$ 4 . 1 0}$ & $\mathbf{\$ 6 . 7 0}$ & $\mathbf{\$ 8 . 5 3}$ \\
\hline
\end{tabular}

The low-end volatility is the annualized historic volatility. This is obtained from calculating the daily instantaneous returns from January 1, 2009, to May 8, 2009, using the procedure outlined in Hull (2003, pp. 238-241) and Wilson (2009). The high-end volatility is also based on historic volatility of the stock from January 1, 2008 to May 8, 2009. The middle volatility estimate is based on the implied volatility of the $\$ 17.50$ June 2009 call options traded on May 8, 2009. The option price data was obtained on www.prophet.net. The stock price data was taken from Yahoo! Finance. The probability that half the warrants will be cancelled is the subjective probability given by the author of the likelihood of a qualified equity offering being completed by December 31, 2009. Completion of a qualified equity offering would allow the bank to cancel half the warrants. The per-warrant value is calculated with the inputs in this table and the stock price and strike price in Table 1 using the Black and Scholes (1973) model with no adjustments for either dilution or dividends. 